In the fell clutch of circumstance

I have not winced nor cried aloud.

Under the bludgeonings of chance

My head is bloody, but unbowed.

Beyond this place of wrath and tears

Looms but the Horror of the shade,

And yet the menace of the years

Finds, and shall find, me unafraid.

It matters not how strait the gate,

How charged with punishments the scroll,

I am the master of my fate:

I am the captain of my soul.

I am grateful to Constable and Co Ltd for permission to reproduce paragraphs and illustrations from John Connell's WE Henley.

1 Wilde $O$. Henley's poems. The Woman's World 1888;3:108-9. (Reprinted in: Lucas EV, ed. A critic in Pall Mall being extracts from reviews and miscellanies by Oscar Wilde. London: Methuen, 1919:123-9.)

2 by Oscar Wilde. London: Methuen, 1919:123-9.) 1888.

3 Cornford LC. William Emest Henley. London: Constable, 1913.

4 Williamson K. W E Henley: a memoir. London: Harold Shaylor, 1930.

5 Buckley JH. William Emest Henley: a study in the "counter-decadence" of the 'nineties. Princeton: University Press, 1945.

6 Connell J (pseudonym of Robertson JH). W E Henley. London: Constable, 1949.

7 Baron JH. Captain of his soul. Medical News 1965;133:18.

8 Goldman M. Lister ward. Bristol: Adam Hilger, 1987.

9 Henley WE. In hospital. The Bibelot: VII (1). Portland: Thomas Mosher, 1901.

10 Henley WE. In hospital: rhymes and rhythms. Portland: Thomas Mosher, 1903.

11 Roudin MB, Moschowitz E. The unpublished poems of "In Hospital" by William Ernest Henley. Bull Inst Hist Med 1936;4:231-41.

\title{
British medical services at the Battle of Waterloo
}

\section{R Howard}

By the morning of 18 June 1815 Wellington had concentrated 67000 men and 156 guns on the ridge of Mont-St-Jean in front of the village of Waterloo. The French army of 72000 men and 246 guns massed on the heights of La Belle Alliance 1400 yards south of the allies. ${ }^{1}$ Napoleon's tactics at Waterloo have variously been attributed to fatigue, overconfidence, and ill health. As Wellington wrote, "He did not manoeuvre at all. He just moved forward in the old style and was driven off in the old style." With the arrival of the Prussians on the French right flank at about $800 \mathrm{pm}$ Wellington counterattacked and Napoleon's last army disintegrated. In the space of about six square miles lay more than 52000 dead and wounded. About 6700 were Prussians, 15000 were from the allied army, and the rest were French.

So how were the British army medical services organised to meet the demands of such a conflict? There is little in the way of official documentation so our knowledge is dependent on numerous fragmentary sources. Essentially the medical services could be divided into three parts: army medical department; ordnance medical department (for the artillery); separate establishment for the household troops.

The army medical department was itself divisible into three: the administrative officers, the hospital or medical staff, and the regimental medical organisation. $^{3}$

Such background information is necessary to unravel the way in which the medical services functioned during the battle itself. We can probably summarise as follows. When a soldier fell wounded on the field it was

Malmesbury, Wiltshire SN16 0BE

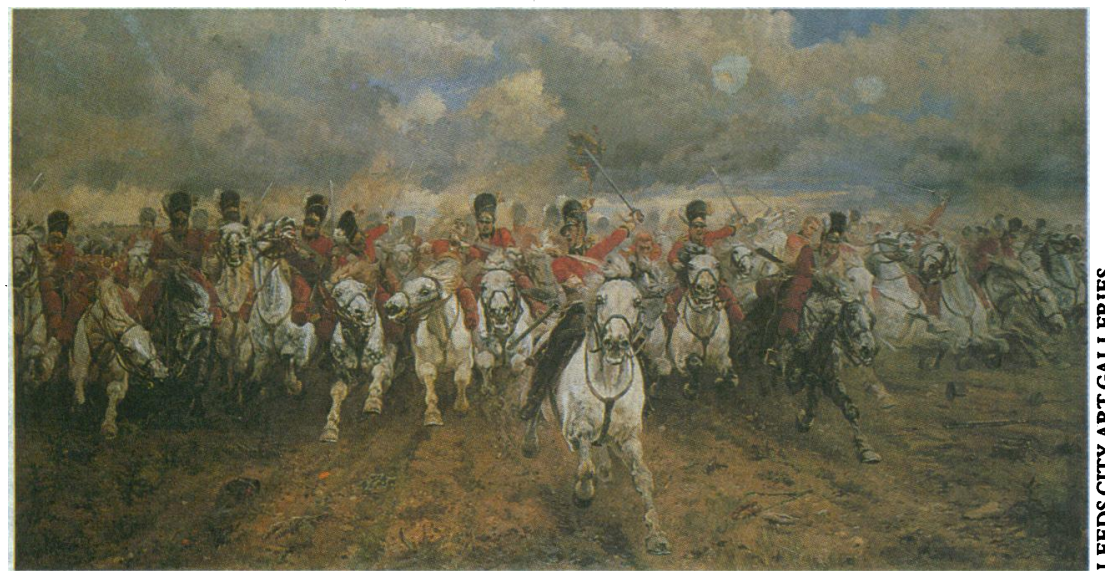

"Scotland for Ever." Lady Butler's dramatic portrayal of the charge of the Scots Greys. quite likely that no help would be forthcoming. If he was lucky, however, either his colleagues or bandsmen would carry him back to receive medical care from the regimental surgeons. There was no equivalent to the flying ambulance of the French instituted by Larrey and it has been estimated that at Waterloo 12000 men were absent having gone to the rear with the wounded.

Early in the battle this first line medical help was provided in brigade dressing stations situated just behind the ridge. As hostilities progressed regimental medical officers were directed to fall back to the temporary hospitals in the houses of Mont-St-Jean and Waterloo and in other buildings behind the line. The wounded reached these facilities either on foot, by stretcher, in country carts, or in the wagons of the royal wagon train. The medical staff were employed at headquarters, along the lines of communication, and in the general and field hospitals. We are told by Howell that a field hospital was opened at Mont-St-Jean three days after the battle. Several general hospitals were in the process of formation at Brussels, Antwerp, Ghent, Bruges, and Ostend. There is little doubt that the medical personnel were overwhelmed by the magnitude of the casualties.

\section{Accounts of the battle}

On the night before the hostilities a huge downpour occurred and most of the regimental surgeons were understandably more concerned with immediate comforts than with the likely toils of the following day. Covered in thick mud, Assistant Surgeon James of the 1st Life Guards, felt himself lucky to find warmth and shelter in a small cottage. ${ }^{5}$ Another assistant surgeon, John Smith, of the 12th Light Dragoons eventually fell asleep in a drain by the roadside, and as the night wore on the water gradually rose through his bundle of straw until he seemed to be lying at the bottom of a leaky boat. ${ }^{6}$

The ferocity of the fighting next day is well detailed in many memoirs. John Kincaid of the 95 th Rifles, a veteran of the Peninsular War, thought that this might be the first battle in which everybody was killed. It is with a certain relish that he relates the tale of two doctors of his brigade who set up their post behind a high, bushy tree. Early in the battle a round shot cut the tree in two and it fell on their heads. Fortunately, only dignity was damaged.?

Assistant Surgeon Gibney wrote, "At first the medical officers remained at the positions occupied by 


\section{Sir Charles Bell's watercolours of the Waterloo wounded}

Each is accompanied by Bell's description of the case

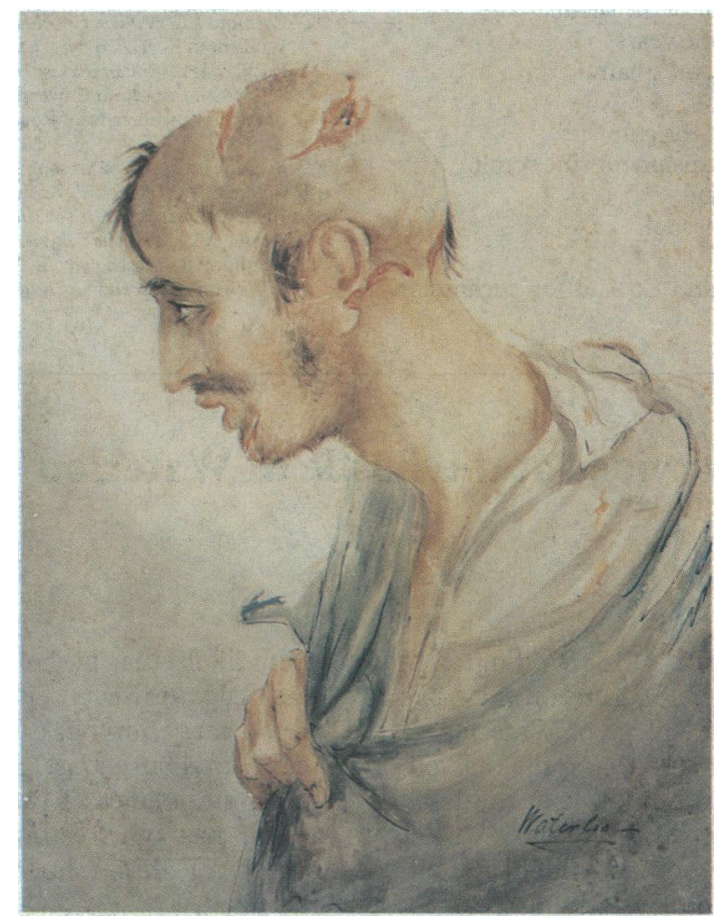

A sabre wound-a portion of the skull at the vertex completely detached by the sabre cut. The soldier belonged to the 1 st Dragoons. He could not speak and stooped languidly with a vacant and indifferent expression of countenance. He was relieved of his symptoms the day after his operation but still could give no account of himself

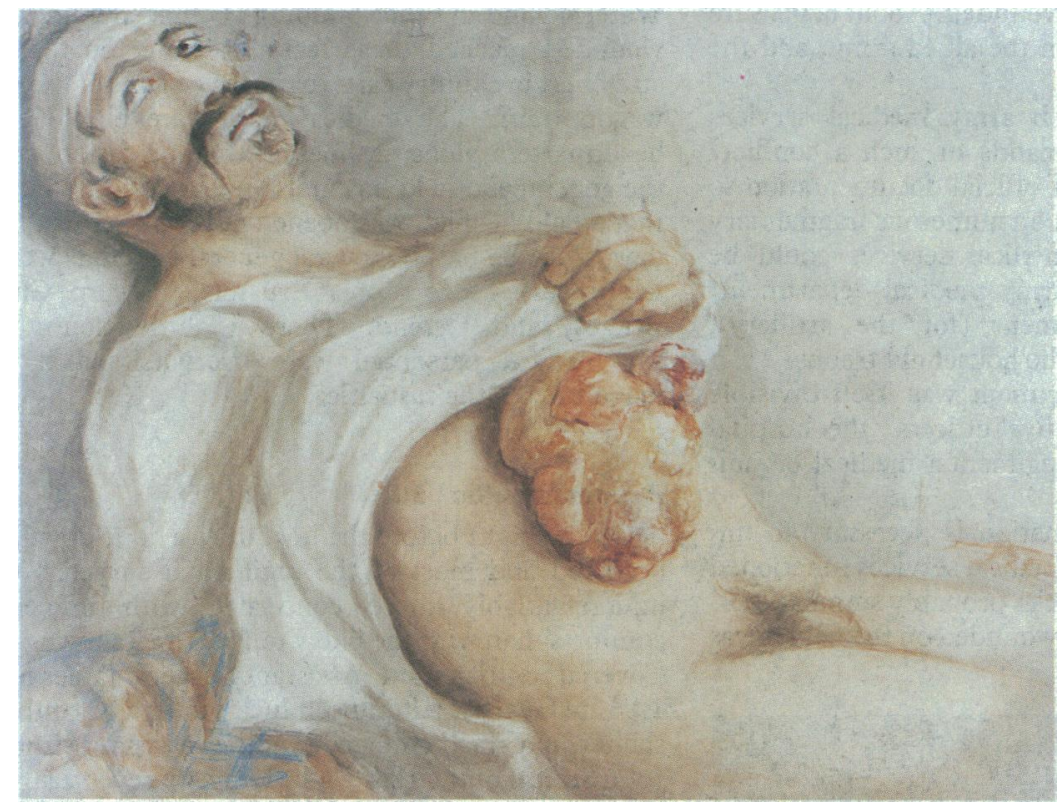

Sabre wound. Colon protruded and completely divided; its ends retracted from each other. Mass was gangrenous when brought to hospital third day after the battle. Recovery took place after a long period

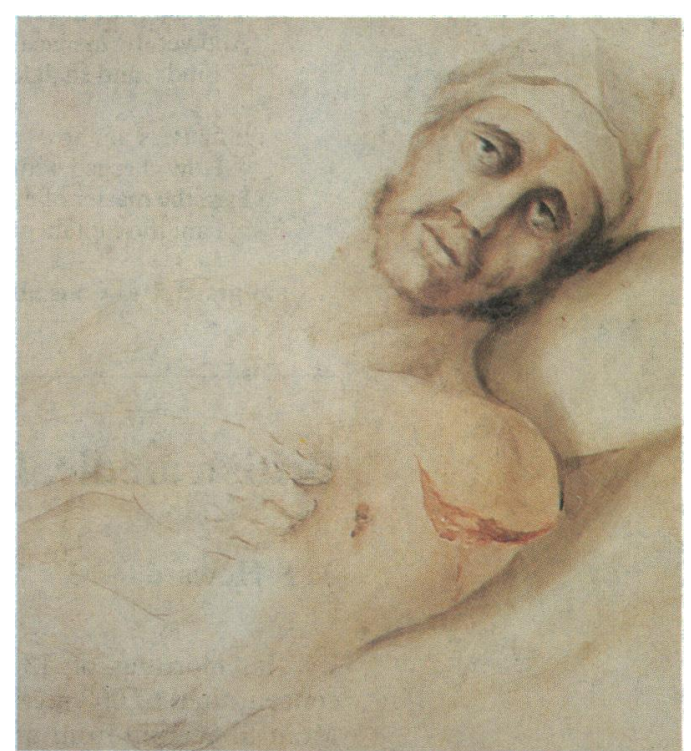

Head of left humerus shattered by gunshot. Head of the bone excised by transverse incision. He was fames Ellard, Pte, 18th Hussars aged 32 years. Three weeks after the operation he was walking about and his countenance was good

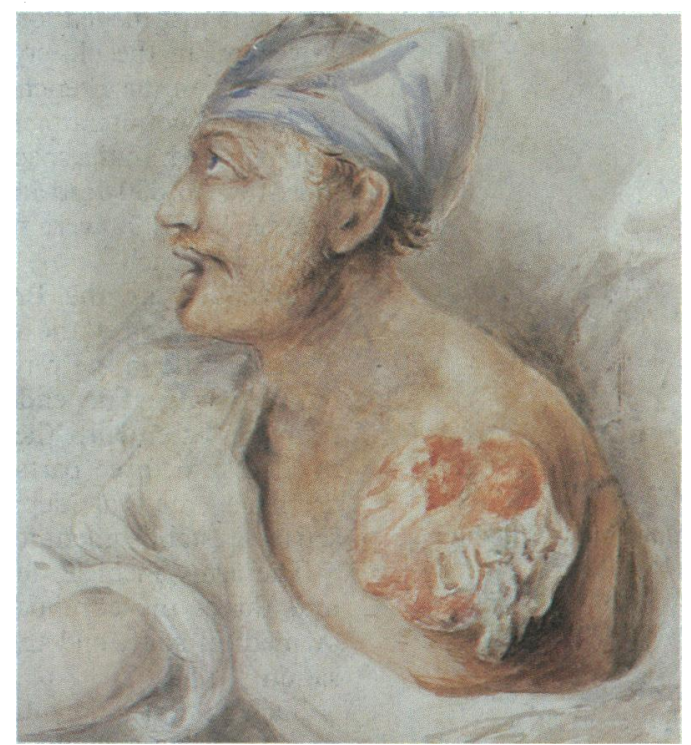

Arm carried off by cannon shot close to the shoulder joint. Patient is Sergt Anthony Tuittmeyer 2nd Line Battalion Kings German Legion. He rode 15 miles into Brussels after being wounded and presented himself at the hospital where he fainted and remained unconscious for 30 minutes. Later he recovered well

RAMC HISTORICAL MUSEUM the regiments at the beginning of the battle and the wounded found their own way back to them. As these positions were exposed to the enemy fire they were directed to take up their quarters in the village of Mont-St-Jean. They found the village full of wounded." We know that other villages and hamlets were also used as, for instance, some of the wounded of the 52nd Regiment were taken to Merbe Braine. ${ }^{3}$ Sergeant Major Edward Cotton says that every home in the neighbourhood was used for the injured and that the farm of Mont-St-Jean was the headquarters, or chief hospital, for the medical staff.' Not only the rooms of the farmhouse but the stables and cowhouses were eventually filled with allied wounded.

Just how effective were the medical personnel in alleviating suffering and saving life is difficult to say. Certainly all treatment was severely hampered by a lack of proper facilities, medical supplies, and fresh water. It is likely that the proficiency of the doctors varied considerably. Not very long before John Hunter 
had written that it was hardly necessary for a man to be a surgeon to practise in the army.

The most common types of wound were due to musket balls, grape shot, and cannon ball, although, of course, incised wounds were also frequent due to the use of lance, sabre, and bayonet. Treatment was uncomplicated, including amputation, probing, stitching, bandaging, and bleeding. Gunshot wounds of the limbs, unless very superficial, would almost certainly lead to amputation. There is little doubt that, in the heat of battle, arms and legs which could easily have been preserved were sacrificed. One officer related how, in returning to the rear, he was saved by enemy fire from three successive surgeons who wanted to amputate his arm, a limb he eventually kept intact. ${ }^{10}$

A controversial issue of the Napoleonic era was that of the optimum time of amputation. It had previously been the practice to not amputate immediately after the wound but to wait for evacuation to hospital or even longer. " Guthrie, however, was in favour of amputation as soon as possible after the injury before "fever, inflammation, suppuration and gangrene" could take their toll. ${ }^{12}$ By the time of Waterloo his views had generally prevailed and most amputations were carried out as soon as was feasible. Probing wounds was done using a combination of bare fingers and musket ball forceps. It was a frequent belief that probing for foreign bodies was easier if the casualty was placed in the position in which he had been at the time of injury. Thus often the patient was held upright and there are even stories of cavalrymen being remounted to have their wounds explored. ${ }^{13}$

The only common practice at Waterloo that was positively harmful was that of bleeding. Soldiers who had received multiple injuries were often initially managed by the letting of large amounts of blood. The importance of shock was simply not understood. As Matheson points out even Guthrie refers to the cardinal signs only in passing. ${ }^{1+}$ George Power, surgeon to the forces, recommended in 1815, "Large and repeated bleedings with peculiar good effect in preventing the onset of gangrene following gun-shot wounds."'15 Most ordinary soldiers had complete faith in the procedure. Colonel Ponsonby of the Scots Greys lay on the field of battle for 18 hours with a probable pneumothorax and several other wounds. He was then taken in a cart to Waterloo village and actively bled by the surgeon, an action to which he attributed his survival.

The diluted spirits and opiates gave scant relief from the agonising pain of amputation. Assistant Surgeon James wrote in his journal: "Our work behind the lines was grim in the extreme, and continued far into the night. It was all too horrible to commit to paper, but this I will say, that the silent heroism of the greater part of the sufferers was a thing I shall not forget." The memoirs of Waterloo abound with stories of fortitude in the face of adversity. Not a word passed during the amputation of the arm of the future Lord Raglan; indeed few were aware of Raglan's presence until he called out in his usual casual voice, "Hello. Don't carry away that arm until I have taken off the ring."

\section{After the battle}

When darkness fell on the field many thousands of men lay helpless within a few square miles. How many were already dead, how many died in the night, and how many eventually had medical attention is impossible to know. With the return of daylight the mammoth task of collecting the wounded and burying the dead began in earnest. Most regiments sent out fatigue parties to collect their own wounded and bring them under shelter for medical attention. But this was a tedious task and certainly the last British wounded were not removed from the field until four days after the battle and French wounded were still being collected from the woods at the beginning of July.

Most of the wagons and medical personnel had accompanied the main body of the army in its advance on Paris. In view of this country carts were requisitioned for the wounded, peasants were encouraged to bury the dead, and the services of local Belgian doctors were enrolled. Every available building near the field was already overflowing with casualties so many had to be taken directly to Brussels. On the uneven cobbled road the unsprung carts met frequent obstacles and the journey took several days. Such was the discomfort of this mode of travel that those who could walk generally preferred to do so. Many wounded were forced off the road and crawled through the undergrowth of the surrounding forest. ${ }^{16}$

\section{Civic help}

Fortunately, much help was forthcoming from the local inhabitants of the city. On the eve of the battle the mayor had invited every citizen to send him all the mattresses, sheets, and blankets they could possibly spare. Such forward planning was well founded for in the event the hospitals were completely overwhelmed and in the streets and squares thousands of wounded were laid on straw. ${ }^{17}$ The doctors were too few in number to attend all the casualties and local ladies worked hard to try and compensate..$^{18}$

The most accessible account of the care of the wounded after Waterloo is John Thomson's Report of Observations made in the British Military Hospitals in Belgium, after the Battle of Waterloo, published in Edinburgh in 1816. Thomson was professor of surgery in the Edinburgh College of Surgeons and regius professor of military surgery in the University of Edinburgh. When reading his observations you must remember that he did not arrive in Brussels until almost three weeks after the conflict. At this time six general hospitals were established in the city with accommodation for 2000 . There were also five further hospitals at Antwerp. Soldiers of all nationalities received treatment, with the wounded at Antwerp faring less well due to a higher incidence of fevers, typhus, and hospital gangrene - $\mathbf{a}$ fact attributed to its low lying position. ${ }^{19}$ Hospital gangrene was that type of gangrene associated with severe, often fatal, infection of amputation stumps and other extensive wounds. Its contagious nature was well established. ${ }^{20}$

In essence, Thomson found that the hospitals that he inspected were spacious and well ventilated, with good food. There was a tendency to collect cases together according to the nature of the wounds that they had suffered. He estimated that 500 amputations were performed after the battles of Quatre Bras and Waterloo, one third before fever set in. Thomson supports Guthrie's views on amputation, saying that the highest mortality was seen in those in whom operation was delayed.

James Simpson, an advocate, was in Antwerp at the same time as Thomson. He visited two of the hospitals in the town and was struck by the difference in the condition of the British and French wounded. In $\mathrm{La}$ Corderie, the hospital for the 1500 French wounded, he says that the cases were almost universally in a worse state and death was much more frequent..$^{21}$

Several civilian doctors visited Brussels during this period to give extra surgical help in the hospitals. Charles Bell, the Edinburgh surgeon, worked 12 hours a day for the first three days of his visit and wrote (on 1 July), "It was thought we were prepared for a great battle, yet, there we are, eleven days after it only making arrangements for the reception of the wounded." Later he added, "All decencies of performing surgical operations were soon neglected. 
While I amputated one man's thigh there lay, at one time, thirteen all beseeching to be taken next. It was strange to feel my clothes stiff with blood and my arms powerless with the exertion of using my knife." ${ }^{22}$ Bell was also a talented artist and his watercolours of the wounded, now in the RAMC Historical Museum, are an evocative record of his work.

Of those patients not fit enough to return to active duty most returned to England, via Ostend, over the following months. Some were not evacuated until early in $1816 .{ }^{3}$ The most severely disabled soldiers were transferred to the York Hospital in Chelsea where Guthrie practised until its dissolution two years later. ${ }^{23}$

1 Chandler DG. The campaigns of Napoleon. London: Weidenfeld and Nicolson, 1978:1065-6.

2 Gurwood J. Selections from the dispatches and general orders of Field Marshall, the Duke of Wellington. London: Murray, 1851:875.

3 Howell HAL. The British medical arrangements during the Waterloo campaign. Proceedings of the Royal Society of Medicine 1924;17:39-50.

4 Dible JH. D J Larrey, a surgeon of the revolution, consulate and empire. Med Hist 1959;3:100-7.

5 Vansittart J. Surgeon fames's joumal 1815. London: Cassell, 1964;28:35.
6 Longford E. Wellington, the years of the sword. London: World Books, 1971:525.

7 Kincaid J. Adventures in the rifle brigade. Glasgow: Richard Drew, 1981:170.

8 Gibney W. Eighty years ago or the recollections of an old army doctor. London: Bellairs, 1896:191;200.

9 Cotton E. A voice from Waterloo. London: Green, 1889:35;264-6.

10 Kempthorne GA. The Waterloo campaign. I R Army Med Corps 1933;60:52-8.

11 Billroth T. Historical studies on the nature and treatment of gunshot wounds from the fifteenth century to the present day. Connecticut: Smith, 1933:77-8.

12 Guthrie JG. On gun-shot wounds of the extremities requiring the different operation of amputation. London: Longmans, 1815:30.

13 Howarth D. Waterloo. A near run thing. Glasgow: Collins, 1968:173.

14 Matheson JM. Comments on the medical aspect of the battle of Waterloo. Med Hist 1966;10:204-7.

15 Power G. Observations on the treatment of gun-shot wounds. Edinburgh Medical fournal 1815;11:429-31.

16 Scott J. Paris revisited in 1815 by way of Brussels including a walk over the field of battle at Waterloo. London: Longman, 1816:164.

17 Brett-James A. Life in Wellington's army. London: George Allen and Unwin, 1972:265.

18 Brett-James A, ed. Edward Costello, the Peninsular and Waterloo campaign. London: Longmans, 1967:155.

19 Thomson J. Report on observations made in the British military hospitals in Belgium after the battle of Waterloo. Edinburgh: W Blackwood, 1816:13;25.

20 Thomson J. Lectures on inflammation. London: Blackwood, 1813:484-5.

21 Simpson J. Paris after Waterloo, a visit to Flanders and the field. Edinburgh: impson J. Paris after Wan

22 Cantlie N. A history of the army medical department. Edinburgh: Churchill Livingstone, 1974:39

23 Anonymous. Biographical sketch of G J Guthrie. Lancet 1850;i:726-36.

\section{Memories of Lord Moynihan}

\section{A conversation between Sir Reginald Murley and John Hosford}

Fohn Hosford was educated at Highgate School and at St Bartholomew's Hospital, where he qualified in 1922, obtaining both the FRCS and MS with the university gold medal in 1925. Having been a consultant surgeon at Barts and several other hospitals he retired in 1960, first to Portugal and then to Clavering in Essex. He discusses his memories of Lord Moynihan with Sir Reginald Murley, a friend and former colleague.

RM: John Hosford, I think I'm correct in saying that you were Lord Moynihan's last private assistant in London?

JH: Yes, I first met Moynihan in 1931, when I was 31 and he had been president of the Royal College of Surgeons for five years. When Moynihan had been at Barts as visiting professor four years earlier he'd started to operate regularly in London at Alfred House, a private hospital run by Lady Carnarvon. At that time he'd got Keynes (later Sir Geoffrey) and Paterson Ross (later Sir James), both of whom were working on the Barts surgical unit, to assist him. When Ross got on to the full staff in 1931 he felt that he shouldn't go on and suggested that I should take his place. He took me to meet Moynihan, who was operating and asked me to hold a lamp so that he could see better into the abdomen. I remember how impressed I was by the politeness with which Moynihan thanked me for holding the lamp so nicely. After that I was his assistant in London until he died.

RM: What was the set up at Alfred House?

JH: Lady Carnarvon had had no training in medicine or surgery at all, but in every case when Moynihan operated she came into the operating theatre gowned up. It was her job to pick the swabs off the floor and hang them up; she was a great talker, but she kept her mouth shut in the theatre.

JH: Ross didn't much like the peculiar set up at Alfred House-but it amused me, and Keynes as well; and Lady Carnarvon was really a kind person.

Moynihan was an excellent technician. Various people who hadn't seen him working were rather dismissive - for instance, (Sir) Heneage Ogilvie said Moynihan was no good.

RM: Heneage could be very dismissive on occasions;

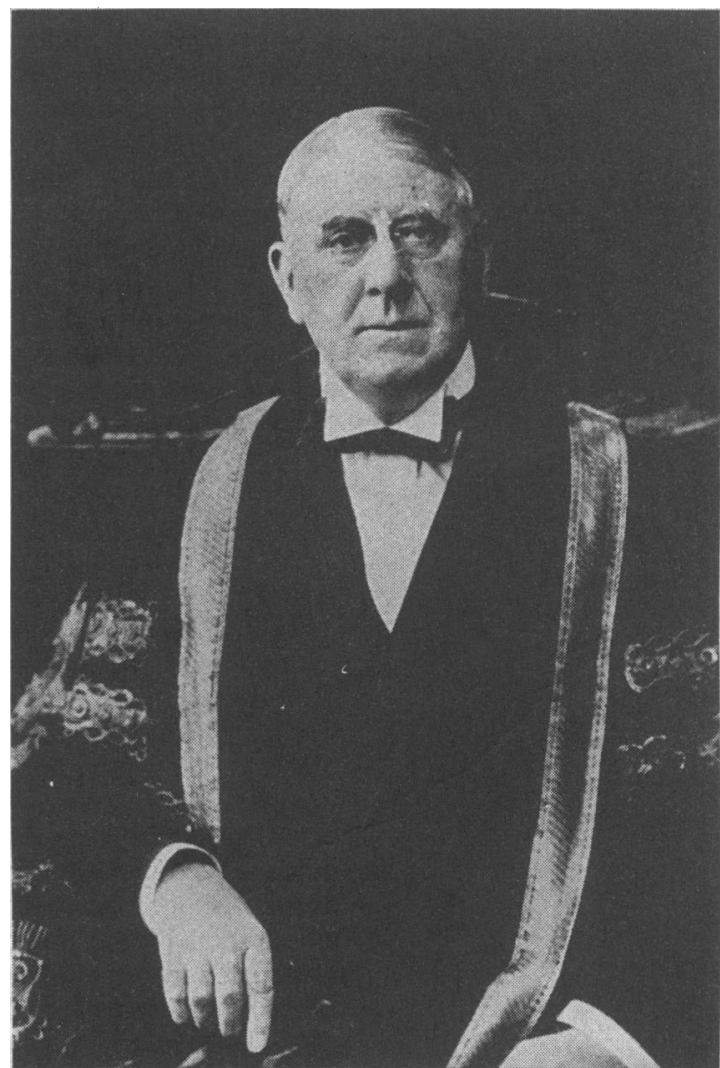

Lord Moynihan. Reproduced by kind permission of the president and council of the Royal College of Surgeons of England

he was a very entertaining speaker-quite scurrilous at times.

JH: Moynihan's famous saying, "I can't do difficult things; I have to make them easy" is a good illustration of what a superb operator he was. To see him operate on a difficult gall bladder was to realise just how light he made of problems. He wasn't a fast operator, saying that a surgeon who has one eye on the clock has one too few on the abdomen.

Another aspect I admired was that Moynihan finished the operation himself, to the point of putting on the 